\title{
Fluoroquinolone-Resistant Escherichia coli and Proteus mirabilis in Poultry of Middle Moravia, Czech Republic
}

\author{
M. KOLÁR̆ ${ }^{1}$, J. BARDOŇ ${ }^{2}$, P. SAUER ${ }^{1}$, M. KESSELOVÁ ${ }^{1}$, L. ČEKANOVÁ ${ }^{1}$, I. VÁGNEROVÁ ${ }^{1}$, \\ D. KOUKALOVÁ ${ }^{1}$, P. HEJNAR $^{1}$ \\ ${ }^{1}$ Institute of Microbiology, Faculty of Medicine, Palacký University, Olomouc, Czech Republic \\ ${ }^{2}$ State Veterinary Institute, Olomouc, Czech Republic
}

Received August 25, 2004

Accepted March 3, 2005

\begin{abstract}
Kolář M., J. Bardoň, P. Sauer, M. Kesselová, L. Čekanová, I. Vágnerová, D. Koukalová, P. Hejnar: Fluoroquinolone-Resistant Escherichia coli and Proteus mirabilis in Poultry of Middle Moravia, Czech Republic. Acta Vet. Brno 2005, 74: 249-253.

The aim of the study was to detect antibiotic resistance of Escherichia coli and Proteus mirabilis isolates from farm-reared poultry.

During the period of June 2003 to June 2004, samples of cloacal swabs obtained from 5 poultry farms located in the central part of Moravia, Czech Republic were examined using aerobic cultivation and afterwards $E$. coli and $P$. mirabilis isolates were identified. Minimal inhibitory concentrations of antibiotics tested were determined by a microdilution method. Pulsed-field gel electrophoresis (PFGE) was performed using SmaI restriction endonuclease.

A total of 300 samples of cloacal swabs from healthy layer hens were cultivated and $239 \mathrm{E}$. coli and 127 P. mirabilis strains were isolated. In the case of E. coli, 7 isolates (3\%) from 4 different farms were identified manifesting resistance to ofloxacin and ciprofloxacin. Out of $24 P$. mirabilis isolates resistant to the tested fluoroquinolones, 20 strains were isolated from one of the farms and PFGE analysis of DNA proved that 19 isolates were probably identical and represented one clonal type.

The study confirmed the occurrence of multiresistant bacterial isolates with resistance to fluoroquinolones in poultry in the Czech Republic. Their clonal spread in farm-reared poultry can be suggested, too.
\end{abstract}

Poultry, faecal bacteria, ofloxacin, ciprofloxacin, resistance

Nowadays, increasing bacterial resistance to antibiotic agents including fluoroquinolones poses a serious problem (Jones et al. 1997; Neu 1992). This adverse trend is documented both in human and veterinary medicine and apparently its solution is to be seen in the synergism of preventive measures (Caprioli et al. 2000; Bogaard and Stobberingh 2000). The increasing bacterial resistance to fluoroquinolones both in human and animal populations is evidently connected with their overuse (Aguiar et al. 1992; Garau et al. 1999; Pena et al. 1995).

In veterinary medicine, fluoroquinolones are used in the treatment of both farm and pet animals. According to the data provided by the Institute for the State Control of Veterinary Biologicals and Medicaments, the overall usage of quinolones in Czech veterinary medicine in 2003 represented $1532.9 \mathrm{~kg}$ (Hera 2005). Many fluoroquinolones used in veterinary medicine belong to "antibiotic agents with indication limits", a group of antibiotics that should be applied in serious animal infections only, based on clinical experience, diagnostic confirmation of the causal microorganism and resistance to "common" antimicrobial agents.

The aim of the study was to detect resistance to antimicrobial agents in Escherichia coli and Proteus mirabilis isolates from poultry bred in the central part of Moravia (Czech Republic), a region with extensive agricultural production. In fluoroquinolone-resistant

Address for correspondence:

Doc. MUDr. M. Kolár̆, Ph.D.

Institute of Microbiology, Faculty of Medicine, Palacký University

Hněvotínská 3

77515 Olomouc, Czech Republic
Tel: +420585632407

Fax: +420585632417

E-mail:kolar@fnol.cz

http://www.vfu.cz/acta-vet/actavet.htm 
isolates, the analysis of genomic DNA was performed and the degree of their similarity determined.

\section{Materials and Methods}

Collection of isolates

During the period of June 2003 to June 2004, samples of cloacal swabs from 5 poultry farms were examined. The farms were located in the central part of Moravia, Czech Republic. The parental breeds produced the final crossbreed of Brown Hissex. In each poultry farm, a total of 60 samples of cloacal swabs were taken from 60 healthy layer hens, i.e. 1 sample per hen. Each clinical sample was cultivated under aerobic conditions on conventional selective media (Endo agar, Xylose-Lysine-Desoxycholate agar). E. coli and P. mirabilis isolates were determined by standard biochemical procedures using Enterotest 24 (Pliva Lachema CZ).

Antibiotic susceptibility testing

Minimal inhibitory concentrations (MICs) of antibiotics tested for E. coli and P. mirabilis isolates were determined by a microdilution method according to the National Committee for Clinical Laboratory Standards guidelines (NCCLS 2000). Concentrations of tested isolates in Mueller-Hinton broth (Oxoid UK) were prepared to obtain $0.5 \mathrm{McF}$ arland turbidity. MICs were read after $18 \mathrm{~h}$ of incubation at $37^{\circ} \mathrm{C}$. The MIC was interpreted as the lowest concentration of the antibiotic that visibly inhibited bacterial growth. As MIC breakpoints, the following values based on the National Institute of Public Health's National Reference Laboratory for Antibiotics recommendations (Urbášková 1998) were used: $1 \mathrm{mg} / \mathrm{l}$ for ciprofloxacin, $2 \mathrm{mg} / \mathrm{l}$ for ofloxacin and tetracycline, $4 \mathrm{mg} / \mathrm{l}$ for ampicillin, cefazolin, cefuroxime, cefotaxime, ceftazidime, chloramphenicol, gentamicin, colistin and meropenem, $8 \mathrm{mg} / 1$ for amikacin, oxolinic acid, trimethoprim and ampicillin/sulbactam, and $32 \mathrm{mg} / 1$ for trimethoprim-sulfamethoxazole and nitrofurantoin. $\mathrm{MIC}_{90}$ and $\mathrm{MIC}_{50}$ include $90 \%$ and $50 \%$ isolates with the given or lower MIC value of the respective antibiotics in the appropriate bacterial species.

Reference strains E. coli ATCC 25922, E. coli ATCC 35218 and Pseudomonas aeruginosa ATCC 27853 were used for protocol quality control.

Molecular analysis of fluoroquinolone-resistant isolates

Pulsed-field gel electrophoresis (PFGE) was performed using SmaI restriction endonuclease. Genomic DNA isolation was carried out using protocols published by Pantůček et al. (1997).

Restriction cleavage of the blocks $1 \times 1 \times 5 \mathrm{~mm}$ was done in restriction solution [ $8 \mu 1$ of restriction buffer for SmaI (Sigma-Aldrich), $65 \mu \mathrm{l}$ of deionised water and $10 \mathrm{U}$ of restriction enzyme SmaI]. The blocks were incubated at $25^{\circ} \mathrm{C}$ overnight.

PFGE was prepared in 1.2\% agarose gel (Amresco) in 1xTBE buffer. PFGE was carried out at BioRad CHEFDR II for $28 \mathrm{~h}$ at a pulse time of 0.1 to $30 \mathrm{~s}, 5.0 \mathrm{~V} / \mathrm{cm}$, with angle $120^{\circ}$. The gel was stained in ethidium bromide solution (Sigma-Aldrich) $(1 \mu \mathrm{g} / \mathrm{ml})$.

The data about administration of antibiotics in observed poultry farms are not available.

\section{Results}

In total, 300 samples of cloacal swabs from poultry (parental breed of Brown Hissex) were cultivated and 239 E. coli and 127 P. mirabilis isolates were identifiety. Antibiotic resistance of the investigated species is given in Table 1. A higher rate of resistant strains in the case of $E$. coli was proved in tetracycline (48\%) and ampicillin (29\%). As for the P. mirabilis strains, higher resistance to trimethoprim (31\%) and trimethoprim-sulfamethoxazole (28\%) was documented, apart from their natural resistance to colistin, nitrofurantoin and tetracycline.

Among E. coli isolates, 7 (3\%) resistant to ofloxacin and ciprofloxacin were isolated from 4 poultry farms, while 4 isolates were detected in farm IV. Out of the $24 P$. mirabilis isolates resistant to the tested fluoroquinolones, 20 were isolated from farm IV (Table 2).

In $E$. coli, 5 other isolates were detected, resistant to oxolinic acid (MICs $\geq 16 \mathrm{mg} / \mathrm{l}$ ), but with persisting sensitivity to ofloxacin and ciprofloxacin. However, MICs of these isolates reached higher values (1-2 mg/l in ofloxacin and $0.5-1 \mathrm{mg} / \mathrm{l}$ in ciprofloxacin).

Fluoroquinolone-resistant isolates of $E$. coli were also resistant to tetracycline, trimethoprim-sulfamethoxazole and trimethoprim; 4 isolates out of 7 were resistant even to gentamicin. P. mirabilis isolates resistant to fluoroquinolones were also resistant to trimethoprim-sulfamethoxazole, trimethoprim and, in $67 \%$, to gentamicin.

In total, 20 fluoroquinolone-resistant isolates of $P$. mirabilis isolated from the same farm 
Table 1. Resistance of Escherichia coli and Proteus mirabilis to antibiotics with $\mathrm{MIC}$ range, $\mathrm{MIC}_{50}$ and $\mathrm{MIC}_{90}$

\begin{tabular}{|c|c|c|c|c|c|c|c|c|}
\hline \multirow[b]{2}{*}{$\begin{array}{l}\text { Antimicrobial } \\
\text { agents }\end{array}$} & \multicolumn{4}{|c|}{ Escherichia coli } & \multicolumn{4}{|c|}{ Proteus mirabilis } \\
\hline & $\begin{array}{l}\text { MIC } \\
\text { range } \\
{[\mathrm{mg} / \mathrm{l}]}\end{array}$ & $\begin{array}{l}\mathrm{MIC}_{50} \\
{[\mathrm{mg} / \mathrm{l}]}\end{array}$ & $\begin{array}{l}\mathrm{MIC}_{90} \\
{[\mathrm{mg} / \mathrm{l}]}\end{array}$ & $\begin{array}{c}\text { resistance } \\
{[\%]}\end{array}$ & $\begin{array}{c}\text { MIC } \\
\text { range } \\
{[\mathrm{mg} / \mathrm{l}]}\end{array}$ & $\begin{array}{l}\mathrm{MIC}_{50} \\
{[\mathrm{mg} / \mathrm{l}]}\end{array}$ & $\begin{array}{l}\mathrm{MIC}_{90} \\
{[\mathrm{mg} / \mathrm{l}]}\end{array}$ & $\begin{array}{c}\text { resistance } \\
{[\%]}\end{array}$ \\
\hline amikacin & $0.125-64$ & 1 & 4 & 1 & $0.5-16$ & 1 & 4 & 2 \\
\hline ampicillin & $0.5-128$ & 2 & 128 & 29 & $0.25-128$ & 1 & 4 & 9 \\
\hline ampicillin-sulbactam & $0.125-8$ & 1 & 4 & 0 & $0.125-4$ & 0.5 & 2 & 0 \\
\hline cefazolin & $0.5-64$ & 2 & 4 & 4 & $1-128$ & 2 & 8 & 7 \\
\hline cefotaxime & $0.06-0.5$ & 0.03 & 0.125 & 0 & $0.03-1$ & 0.03 & 0.125 & 0 \\
\hline ceftazidime & $0.03-0.5$ & 0.03 & 0.125 & 0 & $0.03-0.5$ & 0.03 & 0.125 & 0 \\
\hline cefuroxime & $0.25-32$ & 0.25 & 2 & 1 & $0.25-4$ & 0.25 & 1 & 0 \\
\hline ciprofloxacin & $0.03-8$ & 0.03 & 0.25 & 3 & $0.03-8$ & 0.06 & 2 & 19 \\
\hline colistin & $0.06-2$ & 0.25 & 1 & 0 & $\geq 64$ & - & - & $100 *$ \\
\hline $\begin{array}{l}\text { trimethoprim- } \\
\text { sulfamethoxazole }\end{array}$ & $0.5-512$ & 8 & 128 & 10 & $0.5-512$ & 8 & 64 & 28 \\
\hline chloramphenicol & $0.25-128$ & 1 & 4 & 4 & $0.5-128$ & 1 & 4 & 17 \\
\hline gentamicin & $0.125-32$ & 0.5 & 2 & 2 & $0.125-128$ & 0.5 & 4 & 13 \\
\hline meropenem & $0.03-2$ & 0.125 & 0.5 & 0 & $0.06-0.5$ & 0.06 & 0.25 & 0 \\
\hline nitrofurantoin & $0.5-32$ & 2 & 8 & 0 & $\geq 64$ & - & - & $100 *$ \\
\hline ofloxacin & $0.03-16$ & 0.06 & 1 & 3 & $0.03-32$ & 0.5 & 4 & 19 \\
\hline oxolinic acid & $0.125-64$ & 1 & 4 & 5 & $0.25-128$ & 2 & 16 & 19 \\
\hline tetracycline & $0.25-128$ & 2 & 64 & 48 & $\geq 64$ & - & - & $100^{*}$ \\
\hline trimethoprim & $0.125-128$ & 2 & 8 & 11 & $0.5-64$ & 2 & 16 & 31 \\
\hline
\end{tabular}

* natural resistance

Table 2. Occurrence of fluorochinolone-resistant Escherichia coli and Proteus mirabilis isolates in observed poultry farms

\begin{tabular}{|c|c|c|}
\hline \multirow{2}{*}{ Poultry farm } & \multicolumn{2}{|c|}{ No. of fluoroquinolone-resistant isolates } \\
\cline { 2 - 3 } & E. coli & P. mirabilis \\
\hline I & 1 & 0 \\
\hline II & 0 & 2 \\
\hline III & 1 & 20 \\
\hline IV & 4 & 1 \\
\hline V & 1 & 24 \\
\hline Total & 7 & 0 \\
\hline
\end{tabular}

were analyzed by PFGE. The results are shown in Fig. 1 (see Plate XIII). Of these, 19 isolates were identical and represented one clonal type. A unique isolate shows $60 \%$ similarity of a DNA profile in SmaI spectrum with other probably identical isolates.

\section{Discussion}

The relation between the application of antibiotics and the dissemination of bacterial resistance from animals to humans has been described by Hummel et al. (1996). Also, the study by van den B ogaard et al. (2001) confirmed that transmission of resistant clones and resistance plasmids of $E$. coli from poultry to humans commonly occurs.

$E$. coli is a major pathogen of worldwide importance in commercially produced poultry (Gross 1994). Although this bacterial species is commonly found in the intestinal tract of 
hens, some serotypes can cause diseases. Antibiotic therapy is therefore an important tool for reducing mortality associated with E. coli infections (Dho-Moulin 1993; Gonzáles et al. 1990). On the other hand, the use of antibiotics can select multiresistant bacteria. A study performed in Spain showed the resistance of avian E. coli isolates to ofloxacin and ciprofloxacin in 14\% and 13\%, respectively (Blanco et al. 1997). In the present study, the corresponding value reached $3 \%$. In $P$. mirabilis isolates, the frequency of fluoroquinoloneresistant isolates was much higher. However, it must be stressed that $83 \%$ of the isolates were obtained from one farm, suggesting that these probably originated from one resistant clone. Thus the average resistance level cannot be determined.

Isolates of both species resistant to fluoroquinolones were multi-resistant, manifesting resistance to trimethoprim-sulfamethoxazole, trimethoprim and, in the case of $E$. coli isolates, even to tetracycline. Higher occurrence of gentamicin-resistant isolates was also notified. Similar results were reported by Bazile-Pham-Khac et al. (1996) who described simultaneous resistance to tetracycline, trimethoprim and tobramycin in fluoroquinolone-resistant $E$. coli isolates. It is to be noted that in $E$. coli five other isolates were identified, manifesting resistance to oxolinic acid. Ofloxacin and ciprofloxacin MIC ranges were $1-2 \mathrm{mg} / \mathrm{l}$ and $0.5-1 \mathrm{mg} / \mathrm{l}$, respectively, and, according to the breakpoints applied, these isolates were sensitive to fluoroquinolones. These are probably isolates with single mutations in $g y r A$, i.e. with decreased sensitivity (McDonald et al 2001). This finding should be the first sign of the negative phenomenon of increasing resistance to fluoroquinolones. Therefore, sensitivity testing of gram-negative rods isolated from poultry should involve not only fluoroquinolones, such as ofloxacin or ciprofloxacin, but oxolinic acid as well.

Based on the analysis of the genomic DNA in P. mirabilis isolates resistant to fluoroquinolones and isolated from one of the farms, it is possible to assume that it is most probably one identical isolate spread in the farm.

In conclusion, the results of our study support the occurrence of multiresistant bacterial isolates with resistance to fluoroquinolones in poultry in the Czech Republic and underline the importance of antibiotic policy implementation in veterinary medicine, including monitoring bacterial isolates with dangerous phenotypes of resistance.

\section{Výskyt fluorochinolon-rezistentních kmenů Escherichia coli a Proteus mirabilis v chovech drůbeže na střední Moravě}

Celosvětově stoupající rezistence bakterií $\mathrm{k}$ antimikrobním léčivům představuje vážný problém při terapii infekčních onemocnění i v epidemiologické praxi. Problém bakteriální rezistence je aktuální i v oblasti veterinární medicíny.

Cílem studie bylo zjistit výskyt rezistence $\mathrm{k}$ fluorochinolonům (ofloxacinu a ciprofloxacinu) u kmenů Escherichia coli a Proteus mirabilis izolovaných v 5 chovech drůbeže na střední Moravě. Z každého chovu bylo odebráno 60 kloakálních výtěrů od 60 zdravých slepic. Celkem bylo izolováno 239 kmenů $E$. coli a 127 kmenů $P$. mirabilis. Četnost fluorochinolon-rezistentních kmenů E. coli dosáhla hodnoty $3 \%, \mathrm{v}$ prrípadě P. mirabilis byla rezistence prokázána u 24 kmenů, přičemž 20 pocházelo ze stejného chovu. Kmeny obou species s rezistencí k fluorochinolonům byly multirezistentní se současnou rezistencí k trimethoprim-sulfamethoxazolu, trimethoprimu, u kmenů E. coli rovněž $\mathrm{k}$ tetracyklinu, dále byla pozorována vyšší četnost gentamicin-rezistentních kmenů. Na základě výsledků analýzy genomové DNA 20 fluorochinolon-rezistentních kmenů $P$. mirabilis izolovaných z jednoho chovu, lze s velkou pravděpodobností předpokládat šíření rezistentního klonu jednoho kmene. Z našich výsledků je patrné, že v drůbežích chovech na střední Moravě se vyskytují multirezistentní kmeny $E$. coli a $P$. mirabilis s rezistencí k fluorochinolonům a je tedy nutné vzít v úvahu možnost jejich šíření do lidské populace. 


\section{Acknowledgements}

The study was supported by the IGA grant 1A/8258-3.

\section{References}

AGUIAR JM, CHACON J, CANTON R, BAQUERO F 1992. The emergence of highly fluoroquinolone-resistant E. coli in community-acquired urinary tract infections. J Antimicrob Chemother 29: 349-350

BAZILE-PHAM-KHAC S, TRUONG QC, LAFONT JP, et al 1996. Resistance to fluoroquinolones in Escherichia coli isolated from poultry. Antimicrob Agents Chemother 40: 1504-1507

BLANCO JE, BLANCO M, MORA A, BLANCO J 1997. Prevalence of bacterial resistance to quinolones and other antimicrobials among avian Escherichia coli strains isolated from septicemic and healthy chickens in Spain. J Clin Microbiol 35: 2184-2185

BOGAARD AE, LONDON N, DRIESSEN C, STOBBERINGH EE 2001. Antibiotic resistance of faecal Escherichia coli in poultry, poultry farmers and poultry slaughterers. J Antimicrob Chemother 47: 763-771

BOGAARD AE, STOBBERINGH EE 2000. Epidemiology of resistance to antibiotics. Links between animals and humans. Intern J Antimicrob Ag 14: 327-335.

CAPRIOLI A, BUSANI L, MARTEL JL, HELMUTH R 2000. Monitoring of antibiotic resistance in bacteria of animal origin: epidemiological and microbiological methodologies. Intern J Antimicrob Ag 14: 291-294

DHO-MOULIN M 1993. Les Escherichia coli pathogénes des volailles. Ann Med Vet 137: 353-357

GARAU J, XERCAVINS M, RODRIGUEZ-CARBALLEIRA M, et al 1999. Emergence and dissemination of quinolone-resistant Escherichia coli in the community. Antimicrob Agents Chemother 43: 2736-2741

GONZALEZ EA, BLANCO J, BALODA SB et al 1990. Virulent Escherichia coli strains for chicks bind fibronectin and type II collagen. Microbios 62: 113-127

GROSS WG 1994. Diseases due to Escherichia coli in poultry. In: GYLES, CL (Ed).: Escherichia coli in domestic animals and humans. CAB International, Wallingford, pp. 237-259.

HERA A 2005. Regulace a pravidla, kterým podléhají antibiotika po vstupu do EU. Veterinářství 55: 108-112

HUMMEL R, TSCHÄPE H, WITTE W 1996. Spread of plasmid-mediated nourseothricin resistance due to antibiotic use in animal husbandry. J Basic Microbiol 8: 461-466

JONES RN, BAQUERO F, PRIVITERA G, INOUE M, WIEDEMANN B 1997. Inducible B-lactamase mediated resistance to third-generation cephalosporins. Clin Microbiol Infect 3: 7-20

McDONALD LC, CHEN MT, LAUDERDALE TL, HO M 2001. The use of antibiotics critical to human medicine in food-producing animals in Taiwan. J Microb Immunol Infect 34: 97-102

NEU HC 1992. The crisis of antibiotic resistance. Science 257: 1064-1072

NCCLS 2000. Methods for dilution antimicrobial susceptibility tests for bacteria that grow aerobically. M7-A5. National Committee for Clinical Laboratory Standards, Wayne Pa.

PANTU゚ČEK R, GOTZ F, DOŠKǍ̌ J, ROSYPAL S. 1997. Genomic variability of Staphylococcus aureus and other coagulase-positive staphylococcus species estimated by macro restriction analysis using pulsed-field gel electrophoresis. Int J Syst Bacteriol 35: 25-32

PENA C, ALBAREDA JM, PALLARES R, et al 1995. Relationship between quinolone use and emergence of ciprofloxacin-resistant Escherichia coli in blood-stream infections. Antimicrob Agents Chemother 39: 520-524

URBÁŠKOVÁ P 1998. Rezistence bakterií k antibiotikům - vybrané metody. Praha, Trios 


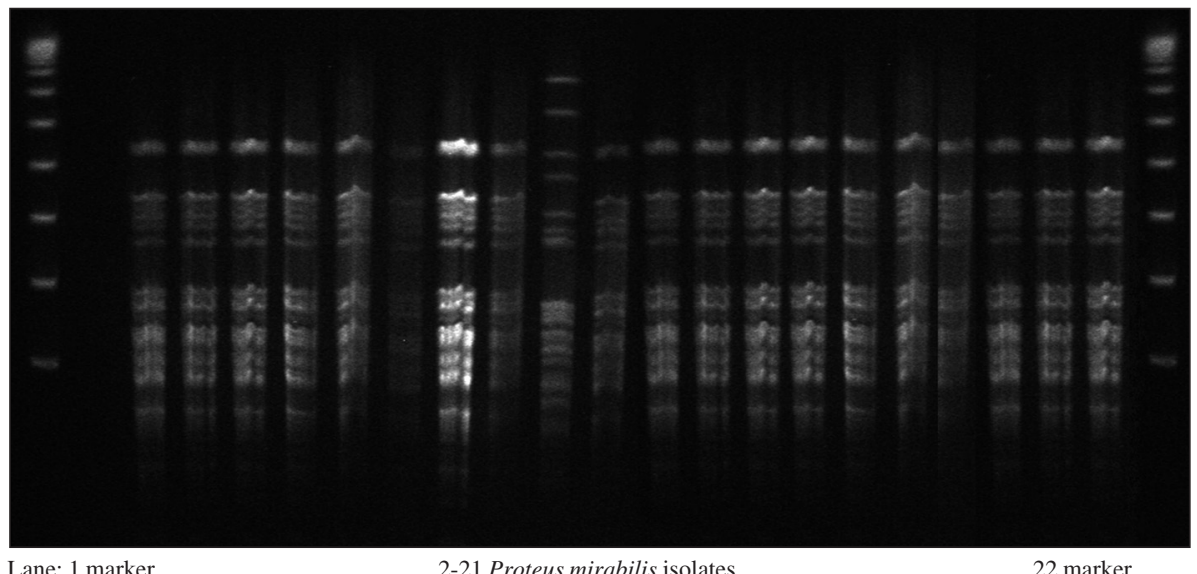

Lane: 1 marker

2-21 Proteus mirabilis isolates

22 marker

Sigma Pulse Marker 50-1000 kB in lanes 1 and 22 was used

Fig. 1 Smal restriction profile of 20 fluoroquinolone-resistant Proteus mirabilis isolates afer PFGE 